\title{
The Implementation of Panca Jiwa in Pesantren Agro Nur El Falah Salatiga
}

\author{
Indonesian Journal of Religion and Society, \\ 2021, Vol. 03 (01), 1-9 \\ (C) The Journal, 2021 \\ DOI: $10.36256 /$ ijrs.v3i1.126 \\ $\underline{\text { www.journal.lasigo.org/index.php/IJRS }}$ \\ layis Nournal \\ Article History \\ Received: February $2^{\text {nd }}, 2021$ \\ Revised: June 9th, 2021 \\ Accepted: June 12th 2021
}

\section{Haryo Aji Nugroho}

IAIN Salatiga, Indonesia

haryoajinugroho@iainsalatiga.ac.id

\section{Winarno}

IAIN Salatiga, Indonesia

winarno@iainsalatiga.ac.id

\section{Rizki Parahita Anindi}

IAIN Salatiga, Indonesia

rizkiparahita@iainsaltiga.ac.id

\begin{abstract}
This study is aimed to describe the implementation of panca jiwa of Agro Nur El Falah Islamic boarding school Salatiga. The data is collected through observation, interview and document. This study shows the concept of the panca jiwa includes sincerity, selfawareness, simplicity, exemplary, compassion. Panca Jiwa has been rule of values in the daily activities of pesantren. However, the implementation of Panca Jiwa has not been maximized at the Pesantren Agro Nur El Falah Salatiga. Several factors inhibiting the implementation of the Five Souls include the lack of cooperation between teachers, the lack of activities that can make students become family to each other, damaged infrastructure and also their personalities at home. Therefore, teachers and senior students must set an example and be more diligent in directing, guiding, educating and supervising students to achieve the desired goals in accordance with the vision and mission of the pesantren.
\end{abstract}

Keywords: Panca Jiwa Values, Pesantren, Education.

\begin{abstract}
ABSTRAK
Penelitian ini bertujuan untuk mendeskripsikan implementasi nilai panca jiwa di Pondok Pesantren Agro Nur El Falah Salatiga. Pengumpulan data dilakukan melalui observasi, wawancara dan studi dokumen. Hasil penelitian menunjukkan bahwa konsep panca jiwa meliputi keikhlasan, kesadaran diri, kesederhanaan, keteladanan, kasih sayang. Panca Jiwa telah menjadi pedoman nilai dalam kegiatan sehari-hari di pesantren. Namun, pelaksanaannya belum optimal di Pesantren Agro Nur El Falah Salatiga. Beberapa faktor penghambat pelaksanaan panca jiwa antara lain kurangnya kerjasama antar guru, kurangnya kegiatan yang dapat membuat santri menjadi keluarga satu sama lain, infrastruktur yang rusak dan juga kepribadian mereka di rumah. Oleh karena itu, guru dan santri senior harus memberi contoh dan lebih rajin mengarahkan, membimbing, mendidik dan mengawasi siswa untuk mencapai tujuan yang diinginkan sesuai dengan visi dan misi pesantren.
\end{abstract}

Kata Kunci: Nilai Panca Jiwa, Pesantren, Pendidikan 


\section{Introduction}

Historically the presence of Islamic education in Indonesia coincided with the entry of Islam in Indonesia (Hamdanah, 2020). Pondok Pesantren is a traditional educational institution where students live together and study under the guidance of a teacher who is widely known as Kyai and has a dormitory for students to stay overnight. It is also part of the national education system that has responsibility of building the character of Indonesian people (Rusydiyah \& Matrapi, 2019). According to Masqon, santri, student of pesantren, would learn on how to become a good Muslim who always obey the commands of God, have good characters, have strong and comprehensive personal features, possess intellectual capability and independent (Karimah, 2018). They are located in a place which also provides a mosque for worship, a space for studying, and other religious activities. This place is usually surrounded by a wall to be able to monitor the entry and exit of the students in accordance with the regulations (Dhofier, 1982).

Pondok Pesantren are two terms that show one meaning. Pesantren, according to its basic meaning, is a place for the students to learn, while pondok means a simple house or residence made of bamboo. In addition, the word pondok may come from the Arabic funduq which means hostel or hotel. Among the objectives and functions of the pesantren are as institutions for the teaching of Islam, so that the area and its surroundings can be influenced in such a way, so that those who previously did not or have never accepted Islam can change to accept it and even become devout followers of Islam. Meanwhile, pesantren as a place to study Islam is because indeed the first and foremost activity of an Islamic boarding school is intended to study and deepen the knowledge of Islam (Usman, 2013).

Education in pesantren generally prioritizes material on religion and morals, but lacks both hard skills and soft skills. As a result, a significant number of pesantren graduates often stutter when they have to live with their society. It is difficult to find work and even if they work, the majority of them become unprofessional workers, like being ordinary traders in traditional markets. There are also many pesantren alumni who are unemployed, even though the amount of money and time they spend studying at the boarding school is not small. It could be up to a dozen years or almost the same as those who received formal education until graduating from college. In fact, like others, the students will face challenges that are no less complex in the era of global competition (Handayani, 2013, p. 2).

Value education is an effort to shape one's attitudes and behavior, this is as stated by Smith and Spranger, that values will affect individual attitudes and actions because they must always be owned. In line with Smith and Spranger, Sari (2013) stated that teaching moral values are important to create human resources who are smart, skilled, have a good character, independent, religious, responsible to the environment and to the nation. Teaching moral values is not only the responsibility of the government, but it should be the concern of every element of the nations, such as schools, families and communities.

In relation to the value level, Hadiwardoyo stated that there has to be a guideline to determine the level of value; the more durable, the higher, the less dependent on other values, the happier and less dependent on certain facts. The process of internalizing values requires proficiency in capturing values through real experiences, including openness of mind, silence, calm, and supportive mental dispositions; open, trusting, honest, humble, responsible, well intentioned, loyal, and obedient. Value education should not be just an addition (complement), but is something that is essential in the entire educational process. Value education becomes increasingly important when the flow of materialism and consumerism globally continues to erode the noble values of human life, not only those who live in big cities, even though they have touched remote villages.

In this boarding school, the educational value that is implemented is called panca jiwa. Panca Jiwa Pondok that may already be familiar because it is explained every welcoming new student. The five souls of the Pondok are Sincerity, Simplicity, Independence, Islamic brotherhood, and Freedom. Five things that are instilled in the souls of all students by the caregiver Islamic boarding school which alumni of the modern pondok Gontor Ponorogo, so it is necessary to see the application of the values of the five souls of the students (Juliono, 2015, p. 3).

There are many previous studies focusing on the implementation of the panca jiwa values. Some of them found that although those values have been conveyed to the students in many occasions, some students still cannot apply these values in their daily lives (Abu et al., 2015). Therefore, this research is carried out to find out whether or not the value of 
panca jiwa pondok is successfully implemented in Agro Nur El Falah Islamic Boarding School, as well as finding out how should these panca jiwa should be implemented.

\section{Literature Review}

As stated above, there are panca jiwa pondok that has become the values of education in many pesantren, such as Pesantren Agro Nur El Falah Salatiga, namely sincerity, simplicity, independence, Islamic brotherhood and freedom. The teaching of these values has been implemented in their daily life, both from teachers or senior students. The aim of teaching these values is so that this panca jiwa can be implemented as the characters of the students in their daily lives. In fact, recently, world of our education including formal, non-formal, and informal education has obstacle and tough challenges. Numerous challenges faced now are moral value degradation, lack of noble morality, and moral crisis happening among students. Therefore, it is really important to study more about the implementation of character education or panca jiwa (Hidayat, 2016).

Character education is a form of activity in which there is an educational activity that is included in the teaching and learning process in order to shape individual self-improvement continuously and to train one's ability to lead to a better life (Hamdanah, 2020; Sarbaitnil \& Firdaus, 2019). Many Islamic boarding schools and schools under government has implemented the teaching of character education because the building of character education is in accordance with the objective of national education of Indonesia.

Many researchers has started to study the implementation of teaching panca jiwa or character building in many institution, both Islamic and government institutions. For instance, Hamdanah (2020) who did the research about the Character Education Santri Based on Panca Jiwa in Shofa Marwa Islamic Boarding School Jember-Indonesia. This study involved the Kyai and Nyai (the guardian) of the boarding school, the teachers and the students as well. The result of this study showed that the formation of the character of students is also done through the five souls of the students, namely the soul of sincerity, the soul of simplicity, the spirit of independence, the spirit of ukhuwah and the free spirit of responsibility. The values of the five souls of students are conveyed not only through lectures and recitation, but the five souls are directly applied to students in their daily lives. The obstacles in implementing this character education based on Pancajiwa santri are, firstly santri backgrounds that are different from economic, sociocultural backgrounds and religious understanding backgrounds, the result of the study show that the kyai and nyai have special strategies in character-based santri education the five souls of the students, namely with the bottom up and top down approach, students are always involved in making policies and implementing the policies of students to what should be done to students who do not obey the rules. Thus, it can be concluded that the implementation of panca jiwa in Shofa Marwa Islamic boarding school still faced difficulties such as the difference in students' background.

Nur Hidayat has carried out a study about The Implementation of Character Education Model at Islamic Boarding School of Pabelan, Magelang, Central Java in 2016. He found that the character education in this boarding school was implemented through social caring, direct learning, simplicity, humanly-based education, role modelling method, moral foundation of politic learning, scientific culture model, local wisdom development, education development, work ethic, self-reliance, and learning to be independent. For example, the teaching of character through role modelling method was performed by the kyai himself as explained by the teacher through interview. The kyai of the boarding school appeared to be tough, firm, smart, has good manners, and never give up to difficult situation. By seeing their kyai, the students can observe and then follow his character. From this study, it can be understood the institutions have their own way to teach the character education or panca jiwa to their students.

While Abu et al., (2015) conducted their research about developing character education in madrasah (schools). About 16 teachers from 6 different schools in South Sulawesi has participated in this study. They were firstly interviewed and observed by the researchers. After that, the result of the interview and observation was discussed through the focus group discussion with the teachers. It can be found that the teachers implemented the character education both contextually and conceptually. Contextually, for example, the teachers teach about caring. The teachers asked the students to make home visits to the student who suffer from pain. But still, there are many factors that hinder the success of the implementation of character education. There are still many students who cannot apply 
or implement the characters that have been taught by their teachers. This method of teaching is in accordance with the result of previous research carried out by Nur Hidayat that the kyai and the teachers become role model to the students so that the students themselves could see and experience it directly.

From these previous research, it can be concluded that many institutions have started implementing character education or panca jiwa in both pesantren (Islamic boarding school) and madrasah (schools). Some institutions implemented it by becoming the role model to the students, while others conveying it through asking the students to experience it themselves. Therefore, this study is intended to find out the implementation of panca jiwa in one of pesantren in Salatiga, namely Agro Nur El-Falah Islamic Boarding School. This pesantren has been implementing this education long time ago.

\section{Method}

The research used in this study is a field research. It is a research activity carried out in a particular community environment, both social institutions and organizations as well as 5 government agencies (J. Moleong Lexy, 2010, pp.81). The research was conducted in Pesantren Agro Nur El Falah which located in Salatiga.

This study employs phenomenological approach, which is an approach used to describe the things that happen to the object of research by describing the events that occur systematically (Helaluddin, 2018). Qualitative research produces describe data in the form of written and spoken words from people and observed behavior.

This study is aimed to describe and analyze the concept of the panca jiwa of Pesantren Agro Nur El Falah Salatiga in building the character of the students in 2020. The pesantren is located at Jalan Dipomenggolo, Pulutan, Kec. Sidorejo, Salatiga, Central Java.

While the subjects of this study were the head of the boarding school, the teachers, the guidance of the students, and the students of the Islamic Boarding School themselves. To obtain valid data, this study uses several kinds of data collection methods, including interview methods, observation methods and documentation methods. The data is then analyzed using the inductive method, which firstly emphasizes and describes the observations and then draws conclusions from these observations. The technique used in testing the validity of the data in this study is by using triangulation technique. This technique is a combination of several data collection techniques and also existing data sources, namely by collecting different data to get data from the same source. In this study observation techniques was used, then interviews, and also documentation on the same data source.

\section{Result and Discussion}

\subsection{Values of Panca Jiwa at Pesantren}

Pondok pesantren is the oldest educational institution in the journey of Indonesian life, which appeared since six centuries ago. Islamic boarding schools in Indonesia are known as the most suitable and intensive places for teaching and learning with the culture of the Indonesian Islamic community. Nugroho (2016) added that since the beginning, pesantren have grown and developed in various regions of Indonesia, and have been known as Islamic institutions that have strategic values in the development of Indonesian society through teaching and learning. Teaching and learning in pesantren is deep-rooted, get support from the community, and live in the community and serve the people (Khuriyah \& Alwiyah, 2016, p. 57).

Islamic boarding schools have distinctive features compared to other educational institutions in Indonesia. Pondok pesantren is an educational institution that specializes in deepening religious knowledge. During its development, there are now many changes starting from a scientific perspective (by starting to adopt general subjects), as well as in other capacities of pesantren institutions which have now become an institution that has complete facilities to build the potential of students not only in terms of morals, values, intellectuals and spirituality, but also in the equipment in it. This is in line with the main objective of establishing Islamic boarding schools, which is to produce scholars or to produce people who study their religion or tafaqquh fi ad-din (Syafe'i, 2017, p. 5).

Islamic boarding schools are the most varied educational institutions given the freedom of their founders to emphasis on certain studies. This emphasis according to Qomar is based on the expertise of the Kyai (Yahya, 2015). The large number of pesantren variations 
needs a categorical distinction. This category can be viewed from various perspectives, in terms of curriculum series, levels of progress and modernity, openness to change and from the point of view of the education system. According to Yahya (2015) in terms of curriculum, Islamic boarding schools can be classified into modern Islamic boarding schools, Islamic boarding schools (tahassus) and mixed pesantren (Yahya, 2015). According to Dhofier from the perspective of being open to the changes that occur, pesantren are divided into salafi and khalafi pesantren (Dhofier, 1982). The first one means conservative, while the last one means adaptive (Tuanaya et al., 2007, p. 5). Further explained by Qomar the differences between traditional and modern pesantren can be identified from their managerial perspective. Modern pesantren have been managed neatly and systematically with general managerial principles. Meanwhile, traditional pesantren run naturally without trying to manage them effectively (Tuanaya et al., 2007).

The value education at the pesantren is called Panca Jiwa Pondok. It is composed of three syllables, they are panca, jiwa and pondok. Panca means five, jiwa means the entire inner life of man (which occurs from feelings, thoughts, dreams, etc.,) and pondok means madrasa and dormitory where the recitation of the Qur'an, study Islam, etc. It can be understood that Panca Jiwa Pondok are five things that emerge and are firmly planted in the hearts of the teachers and the students to live their daily lives in the Islamic boarding school. The five spirits of this pesantren do not automatically appear and then are published to the students in Gontor, but it takes a long time for KH. Imam Zarkasyi to really solidify the results of his thinking about the five spirits of the pesantren. While the five spirits of this pesantren were born after going through a crystallization process which includes the process of observation, appreciation, and studying the ups and downs of various Islamic boarding schools, especially Pondok Gontor, as well as input from various parties, especially his relatives. namely KH. Ahmad Sahal and KH. Zainuddin Fanani. The five souls of this pesnatren were officially published by KH. Imam Zarkasyi at the Seminar on All Indonesian Islamic Boarding Schools in Yogyakarta from 4 to 7 July 1965 (Haikal, 1996, p. 882). Thus, $\mathrm{KH}$. Imam Zarkasyi about the five spirits of pesantren, they are:

\subsubsection{Sincerity}

Sincerity is doing something not because it is driven by the desire to get certain benefits. Sodikin, Barlian, Sauri, \& Nurulhaq (2020) added that sincerity can be a form of directed effort in obtaining a result by using the purity of his heart as a manifestation of his own glory in order to wish Allah's blessing alone. All actions are carried out with the sole intention of worship. Hard work is a behaviour that shows serious efforts in overcoming various obstacles to learning and assignments, and completing tasks as well as possible. Then the students will learn and do good deeds seriously and sincerely because their worship and learning are based on a spirit of sincerity, so that it is in accordance with the character education of hard work because with sincerity the work will be done as well as possible.

\subsubsection{Self-awareness}

Self-awareness is aware of each other's position, the students are aware that they are studying and teachers also realizes that he himself is becoming a teacher and an example for his students, so that he is aware of their respective duties. Discipline is an action that shows orderly behaviour and obeys various rules and regulations. With a spirit of awareness, the students and the teachers will carry out their respective duties in an orderly manner, the students are aware that they are learning so that the rules made by the lodge will be obeyed so that with a spirit of awareness the students will learn disciplined character education.

\subsubsection{Simplicity}

The spirit of simplicity is an attitude not to overdo it, to facilitate oneself as needed or in other words, zuhud. Creative is thinking and doing something to produce new ways or results from something that is already owned With a spirit of simplicity, the facilities provided by the cottage have been made in moderation and students must make the best use of existing facilities such as making a magnificent stage that only uses plywood, so the 
students will think and look for new ways to get magnificent but simple results, with Thus, students will learn creative character education from a spirit of simplicity.

\subsubsection{Exemplary}

An exemplary spirit is that everyone must be ready to be a good example for others. The character of responsibility is the attitude and behaviour of a person to carry out his duties and obligations that should be done to himself, society, the environment (natural, social and cultural), the State, and God Almighty. With an exemplary spirit, each student will maintain his attitude and behaviour so that he will always be a role model for other santri, especially for students who also have an obligation to work programs, so from this exemplary spirit students will learn responsibility character education.

\subsubsection{Compassion}

The soul of compassion becomes the foundation for the discipline of pesantren not to resent one another, nurturing with those who are nurtured. Peaceful love is an attitude, speech, and action that causes other people to feel happy and secure in their presence.

With a spirit of compassion, the relationship between students and teachers and supervisors will always be harmonious and there is no grudge between those who are cared for and those who are caring for them or between administrators and members so that an atmosphere of peace and security is formed from here students will learn peace-loving character education. All the values of character education contained in the author's five spirits concepts are compiled with the matric table below:

Table 1. Concept of Panca Jiwa Pondok Pesantren in the Academic Year 2019/2020

\begin{tabular}{|c|c|c|c|}
\hline No & $\begin{array}{c}\text { Panca } \\
\text { Jiwa }\end{array}$ & Activities & Characters \\
\hline 1 & Sincerity & $\begin{array}{l}\text { 1. Each student, with the intention of worship, cleans } \\
\text { pesantren's environment every Friday } \\
\text { 2. The students go to the mosque to perform } 5 \text { times } \\
\text { prayer } \\
\text { 3. The students take their side dish in the kitchen } \\
\text { according to their amount }\end{array}$ & Hard working \\
\hline 2 & $\begin{array}{l}\text { Self- } \\
\text { awareness }\end{array}$ & $\begin{array}{l}\text { 1. The students take a bath at the appointed time by } \\
\text { queuing orderly without command } \\
\text { 2. The students take a bath, eat, and wash clothes with } \\
\text { their own utensils } \\
\text { 3. Every santri is aware that he is studying then learn as } \\
\text { much as they can. }\end{array}$ & $\begin{array}{l}\text { Disciplined } \\
\text { Independent } \\
\text { Curiosity }\end{array}$ \\
\hline 3 & Simplicity & $\begin{array}{l}\text { 1. Organizing joyous stage activities with sufficient funds } \\
\text { 2. Language section give awards to the students who are } \\
\text { most disciplined in using language } \\
\text { 3. Every santri studies, worships and does activities with } \\
\text { the same facilities regardless of social background }\end{array}$ & $\begin{array}{l}\text { Creative } \\
\text { Appreciative } \\
\text { Social } \\
\text { awareness }\end{array}$ \\
\hline 4 & Exemplary & $\begin{array}{l}\text { 1. Language section members do not speak Indonesian or } \\
\text { their vernacular } \\
\text { 2. The election of chief of students' organization through } \\
\text { the aspirations of students. } \\
\text { 3. Every santri is in charge with their respective food } \\
\text { waste after eating. }\end{array}$ & $\begin{array}{l}\text { Responsible } \\
\text { Democratic } \\
\text { Environment } \\
\text { awareness }\end{array}$ \\
\hline 5 & Compassion & $\begin{array}{l}\text { 1. Giving advice to students who are not disciplined } \\
\text { without judging them } \\
\text { 2. Caring to each other and leaning together }\end{array}$ & $\begin{array}{l}\text { Loving peace } \\
\text { Islamic } \\
\text { brotherhood and } \\
\text { communicative }\end{array}$ \\
\hline
\end{tabular}

\subsection{Factors that Support and Inhibit the Implementation of Panca Jiwa}

The factors, in the Kamus Besar Bahasa Indonesia (Suharso \& Retnoningsih, 2012, p. 137) are something, circumstances, events, and parts of it that contribute to, influence the occurrence of something. Likewise, the implementation of educational values in the five 
souls of this pondok also has several factors, both supporting factors and inhibiting factors. Every success of a job, program, system, process or whatever is inseparable from the supporting factors, be it factors that are planned or unexpected or beyond human expectations. And vice versa, inhibiting factors also become obstacles in the implementation of activities. Likewise, the implementation of the five souls of the Islamic boarding school in life at the Agro Nur El Falah Islamic boarding school in Salatiga cannot be separated from the factors that support and hinder. Broadly speaking, these factors are summarized into 2 , namely the environment and human resources (HR).

\subsubsection{Supporting factors}

The supporting factors for the implementation of the values in the panca jiwa pondok are divided into 2 (two), namely environmental factors and human resource (HR) factors.

1. Environmental factors, namely; 1). Facilities are sufficient to help the educational process, it's just that the use and maintenance are still lacking. 2). Policy making can be issued by the head of the Majlis Ma'arif as the coordinator of all activities starting from planning, implementation and evaluation. 3) Students' learning activities, both from a scientific and disciplinary perspective it has been arranged in such a way by looking at the condition of the students and teachers. 4). Support from the surrounding community, the aghniya and the government that has been become a regular and non-permanent donor who provides assistance to cottage, both physically and non-physically.

2. Human resource factors, namely; 1). The background of teachers comes from different pesantren so that they can contribute to the management of pesantren. 2) SMP/SMK teachers who are active and always ready to help run the pondok program. 3). Dedication students who spend time, energy, and thoughts to help the boarding school. 4). Santri who have the willingness and enthusiasm for learning are high, so they actively participate in every activity and obey the rules. 5). There is a good approach in the implementation of education at the Agro Nur El Falah Islamic boarding school. 5). Parents' trust to entrust their children to the boarding school has become a spirit for the caregivers and the teacher's council to educate the students. 6). A sense of social responsibility for the caregiver and the teacher's council and a passion for seeking the pleasure of Allah.

\subsubsection{Inhibiting factors}

Likewise, the inhibiting factors for the implementation of inner values of panca jiwa pondok is divided into 2 (two), namely environmental factors and factors human resources (HR). a. Environmental factors, namely; 1). Less well-maintained learning facilities, for example computers that are damaged and have not been repaired, class desks that are damaged and are still in use. 2). The policies and systems that have been built are quite good, but in their implementation, there is often miscommunication, be it caregivers, teachers, or students. $b$. Human resource (HR) factors, namely; 1 ). The number of teachers who live in the lodge is very minimal to supervise, guide, direct, educate more than 150 students. This results in a lack of supervision of the students. 2). Communication between teachersis not optimal so that the policies taken sometimes conflict with caregivers. 3). Santri come from different areas and of course have different habits, especially students who come from outside Java. This is what often causes differences in perceptions and even ends in fights. Santri rarely receive pocket money from their parents, which causes them to dare to steal their own theme.

\section{Conclusion}

Based on the results of the study, it can be concluded that there are 5 values in the five souls of the Pesantren Agro Nur El Falah Salatiga, namely Sincerity, Simplicity, Independent, Islamic brotherhood, Freedom. Sincerity "sepi ing pamrih rame ing gawe" does not expect rewards or replies from others, no matter how big it is done. When we are sincere, God willing, the reward from Allah is much greater. Simplicity, showing what it is, be it clothes, actions, thoughts, actions according to our level. In simplicity there are values of strength, ability, fortitude and self-control in the face of life's struggles. Independent, standing on one's own feet, independent, the ability to take care of oneself without depending on others. Islamic brotherhood is a brotherhood in the bonds of Islamic law. All Muslims are our brothers, regardless of ethnicity, skin colour, customs, and even Islam also 
recommends that we keep inviting cooperation with non-Muslims in terms of goodness. Freedom, at the Islamic boarding school students are free to think, work, act, innovate, as long as it is in accordance with the place, time, purpose and does not conflict with applicable rules. Not only at the pesantren, but when they graduate, the students are free to determine their own way of life according to their conscience, not violating Islamic law and applicable laws and regulations.

While the results of the interview showed that the implementation of educational values in the five spirits of this pondok is still need to be enhanced, even though there are students who have practiced the values of panca jiwa. It takes extra supervision and guidance from all elements of pesantren for the sake of achieving the values of the five spirits of pesantren.

Factors supporting the implementation of the values in the five spirits of pondok are divided into 2 (two), namely environmental factors and human resource (HR) factors. Environmental factors consist of adequate facilities, well-designed activities. Human resources include various basic teachers, community service students, local community assistance, donors who always provide assistance for the boarding school.

The factors inhibiting the implementation of the values in the five spirits of pondok are divided into 2 (two), namely environmental factors and human resource (HR) factors. Environmental factors are due to lack of maintenance, policies, and activities that have not been implemented optimally. Inadequate human resources, the personality of the students who are still carried away and cause many violations.

\section{References}

Abu, L., Mokhtar, M., Hassan, Z., \& Suhan, S. Z. D. (2015). How to Develop Character Education of Madrassa Students in Indonesia. Journal of Education and Learning (EduLearn), 9(1), 79-86. https://doi.org/10.11591/edulearn.v9i1.768

Dhofier, Z. (1982). Tradisi Pesantren, Studi Tentang Pandangan Hidup Kyai. LP3ES.

Haikal. (1996). K.H. Imam Zarkasyi Di Mata Umat. Gontor Press.

Hamdanah. (2020). Character Education Santri Based On Panca Jiwa In Shofa Marwa Islamic Boarding School Jember - Indonesia. The International Journal of Health, Education and Social (IJHES), 3(3), 11-24. https://doi.org/10.1234/ijhes.v3i3.79

Handayani, R. (2013). Kewirausahaan Berbasis Pesantren.

Helaluddin. (2018). Mengenal Lebih Dekat dengan Pendekatan Fenomenologi: Sebuah Penelitian Kualitatif. Uin Maulana Malik Ibrahim Malang, 4(March), 1-15.

Hidayat, N. (2016). The Implementation of Character Education Model at Islamic Boarding School of Pabelan, Magelang, Central Java. Jurnal Pendidikan Islam, 5(2), 431. https:/ / doi.org/ 10.14421/jpi.2016.52.431-455

Juliono. (2015). Implementasi Nilai-Nilai Panca Jiwa Pondok bagi Santri di Pondok Pesantren Agro Nur El Falah. IAIN Salatiga.

Karimah, U. (2018). Pondok Pesantren, dan Tujuan Pendidikan: Relevansinya dalam Tujuan Pendidikan. Misykat, 03(01), 137-154.

Khuriyah, K., \& Alwiyah, N. (2016). Model Pengelolaan Pesantren Mahasiswa Fakultas Ilmu Tarbiyah dan Keguruan IAIN Surakarta. At-Tarbawi: Jurnal Kajian Kependidikan Islam, 1(1), 91. https://doi.org/10.22515/attarbawi.v1i1.33

Nugroho, W. (2016). Peran Pondok Pesantren dalam Pembinaan Keberagamaan Remaja. Mudarrisa: Jurnal Kajian Pendidikan Islam, 8(1), 89-116. https://doi.org/10.18326/mudarrisa.v8i1.89-116

Rusydiyah, E. F., \& Matrapi. (2019). Character Education in Indonesian Pesantren. Proceedings of the 1st Raden Intan International Conference on Muslim Societies and Social Sciences, 492, 17-21. https://doi.org/10.2991/assehr.k.201113.004

Sarbaitnil, \& Firdaus. (2019). The Character Values In Minangkabau Traditional Martial Arts. International Journal of Scientific \& Technology Research, 8(10), 846-850. www.ijstr.org

Sari, N. (2013). The Importance of Teaching Moral values to The Students. Journal of English and Education, 1(1), 154-162.

Sodikin, O., Barlian, U. C., Sauri, S., \& Nurulhaq, D. (2020). Management of Character Education Based on Panca Jiwa in Pondok Pesantren Darul Muttaqien Bogor. International Journal of Nusantara Islam, 8(2), $172-180$. https://doi.org/10.15575/ijni.v8i2.10776

Suharso, \& Retnoningsih, A. (2012). Kamus Besar Bahasa Indonesia. Widya Karya.

Syafe'i, I. (2017). Pondok Pesantren: Lembaga Pendidikan Pembentukan Karakter. Al- 
Tadzkiyyah: Jurnal Pendidikan Islam, 8(Mei), 85-103.

Tuanaya, M. T., Farida, A., \& Ali, H. (2007). Modernisasi Pesantren. Balai Penelitian dan Pengembangan Agama.

Usman, M. I. (2013). Pesantren Sebagai Lembaga Pendidikan Islam (Sejarah Lahir, Sistem Pendidikan, dan Perkembangan Masa Kini). Al Hikmah, 14(1), 101-119.

Yahya, F. A. (2015). Problem Manajeman Pesantren, Sekolah, Madrasah: Problem Mutu dan Kualitas Input-Proses-Output. El-Tarbawi, 8(1), 93-109. https://doi.org/10.20885/tarbawi.vol8.iss 1.art6 